\title{
Ovarian adrenal rest fumor in congenital adrenal hyperplasia: Is medical treatment the first line option?
}

Ronit Koren ${ }^{1,2}$

https://orcid.org/0000-0002-7236-5354

Shlomit Koren $2,3,4$

https://orcid.org/0000-0003-0676-8865

Alla Khashper ${ }^{2,5}$

https://orcid.org/0000-0002-0737-1643

Carlos Benbassat ${ }^{2,3}$

https://orcid.org/0000-0001-9659-5018

Marina Pekar-Zlotin ${ }^{2,6}$

https://orcid.org/0000-0001-5776-8633

Zvi Vaknin 2,6

https://orcid. org/0000-0003-1086-6644
1 Department of Internal

Medicine A, Shamir Medical Center, Zerifin, Israel

${ }^{2}$ Sackler Faculty of Medicine, Tel-Aviv University Tel-Aviv, Israel

${ }^{3}$ Endocrine Institute, Shamir Medical Center, Zerifin, Israel

${ }^{4}$ Diabetes Unit, Shamir Medical

Center, Zerifin, Israel

${ }^{5}$ Department of Diagnostic

Imaging, Shamir Medical

Center, Zerifin, Israel

${ }^{6}$ Department of Obstetrics and

Gynecology, Shamir Medical

Center, Zerifin, Israel

\section{SUMMARY}

Ovarian adrenal rest tumors (OARTs) are very rare. We describe a case of a young woman with uncontrolled classical congenital adrenal hyperplasia $(\mathrm{CCAH})$, presenting with bilateral OARTs, successfully treated with steroid replacement. A 20 -year-old woman, known to have $210 \mathrm{H}-\mathrm{CCAH}$, presented with severe abdominal pain, vomiting, diarrhea, and fever. As a result of poor compliance, 6 months before her admission hirsutism worsened and amenorrhea, hyperpigmentation, and weakness developed. ACTH levels were $278<\mathrm{pmol} / \mathrm{L}$ and $170 \mathrm{HP} 91.3 \mathrm{nmol} / \mathrm{L}$. She was admitted for parenteral antibiotics and high-dose hydrocortisone treatment. CT revealed bilateral juxta-ovarian masses $(6.2 \times 3.6 \times 7.4 \mathrm{~cm}$ left and $5 \times 2.2 \times 3.2 \mathrm{~cm}$ right) that on MRI were iso-intense in T1 and hypointense in T2, with early enhancement and rapid washout. One week of high-dose hydrocortisone resulted in significant clinical and laboratory improvement and the patient was discharged with $2 \mathrm{mg}$ dexamethasone/day. One month later US revealed shrinkage of the masses and dexamethasone dose was decreased. At three months from discharge, she has resumed regular menses, and a repeated MRI revealed the para-ovarian masses have shrunk. One year after the diagnosis, the para-ovarian masses have shrunk more to $2.8 \times 1.9 \times 4.3$ on the left and $2.1 \times 0.9 \times 1.2$ on the right with less contrast enhancement in comparison to previous test possibly due to fibrotic changes of the tissue. OARTs are rare tumors with a poorly known natural history, and surgery has been the first option in the few reported cases. We demonstrate that medical treatment is a good alternative, leading to significant tumor shrinkage over a short period. Arch Endocrinol Metab. 2021;65(6):841-5

Correspondence to:

Ronit Koren

Department of Internal Medicine A,

Shamir Medical Center

7030000 - Zerifin, Israel

ronitkoren@gmail.com

Received on Sept/22/2020

Accepted on July/21/2021

DOI: $10.20945 / 2359-3997000000415$

\section{INTRODUCTION}

The development of gonadal adrenal rest tumors 1 is a benign complication of congenital adrenal hyperplasia $(\mathrm{CAH})$. They probably derive from adrenal cells that migrate with the gonad during fetal development (1). Their growth is usually attributed to poor medical control, but in some cases, the pathogenesis is less clear (2). Adrenal rests are more common in males (testicular adrenal rest tumors, TARTs) and rarely persist into adulthood. Less than 20 cases of ovarian adrenal rest tumors (OARTs) have been reported, and all but one surgically treated (Table 1). We describe a case of a young woman with uncontrolled classical CAH who presented with bilateral para-OARTs that were successfully treated with steroid replacement therapy.

\section{CASE REPORT}

A 20-year-old woman presented to the emergency room with severe abdominal pain, vomiting, diarrhea, and fever. She was known to have salt losing classical 
$\mathrm{CAH}$ treated with mineralocorticoids (fludrocortisone 0.1 ) and glucocorticoids ( $10 \mathrm{mg}$ twice daily or 3 times daily alternately). Biochemical data leading to her diagnosis of salt-losing classical $\mathrm{CAH}$ at birth were lacking. Moreover, virilization caused clitoromegaly and congenital labial adhesion, separated by urologic surgery at the age of 3 . The patient's menarche was at 13 years old, and she was graded Tanner Stage 5 and had hirsutism (Ferimman-Galley 16) and acne. She reached a final height of $161 \mathrm{~cm}$.

According to genetic testing carried out at diagnosis, she was a heterozygous carrier of the V281L mutation of the CYP2I gene. Genetic screening was carried out many years ago, with only a few mutations found (cluster E6, Q318X, V281L, I2 splice, I172N, P30L, 8bP del). A deletion of the second allele could not be ruled out given the assays available at the time. Since the test did not correlate with the severity of the phenotype, the patient was advised to repeat genetic counseling several times as follow-up but did not proceed with the tests. A phenotype-genotype discordance was found in previous studies exploring the spectrum of disease severity in $\mathrm{CAH}$, and although rarely, V281L mutation has been associated with salt-losing CAH (when sequencing of the entire gene was not performed) (3).

As a result of the patient's poor compliance, six months prior to her presentation, the hirsutism worsened and amenorrhea, hyperpigmentation, and weakness developed. On admission, she had orthostatic hypotension, diffuse abdominal tenderness, and hyperpigmentation of the skin, mainly of the palms, nipples, and face. Laboratory results revealed leukocytosis of $17.4 \mathrm{k} / \mathrm{uL}$ (4-11), hyponatremia of 131 mmol/L (135-145), and elevated C-reactive protein (CRP) levels (343 mg/L). Adrenocorticotropic hormone $($ ACTH) level was $>278 \mathrm{pmol} / \mathrm{L}$ (1.110.1), consistent with very poor compliance, and the 17-hydroxyprogesterone (17OHP) level was $91.3 \mathrm{nmol} / \mathrm{L}$ (follicular phase 0.9-2.7, luteal phase 0.9-7.57). Parenteral antibiotics and a high-dose hydrocortisone $(100 \mathrm{mg} / 3$ daily) treatment were initiated, though no specific pathogen was documented in the blood or urine. A computed tomography (CT) scan (Figure 1) revealed large bilateral para-ovarian masses measuring $4.6 \times 3.3 \times 7 \mathrm{~cm}$ on the left and $2.5 \times$ $1.6 \times 3.9 \mathrm{~cm}$ on the right; the adrenal glands were also
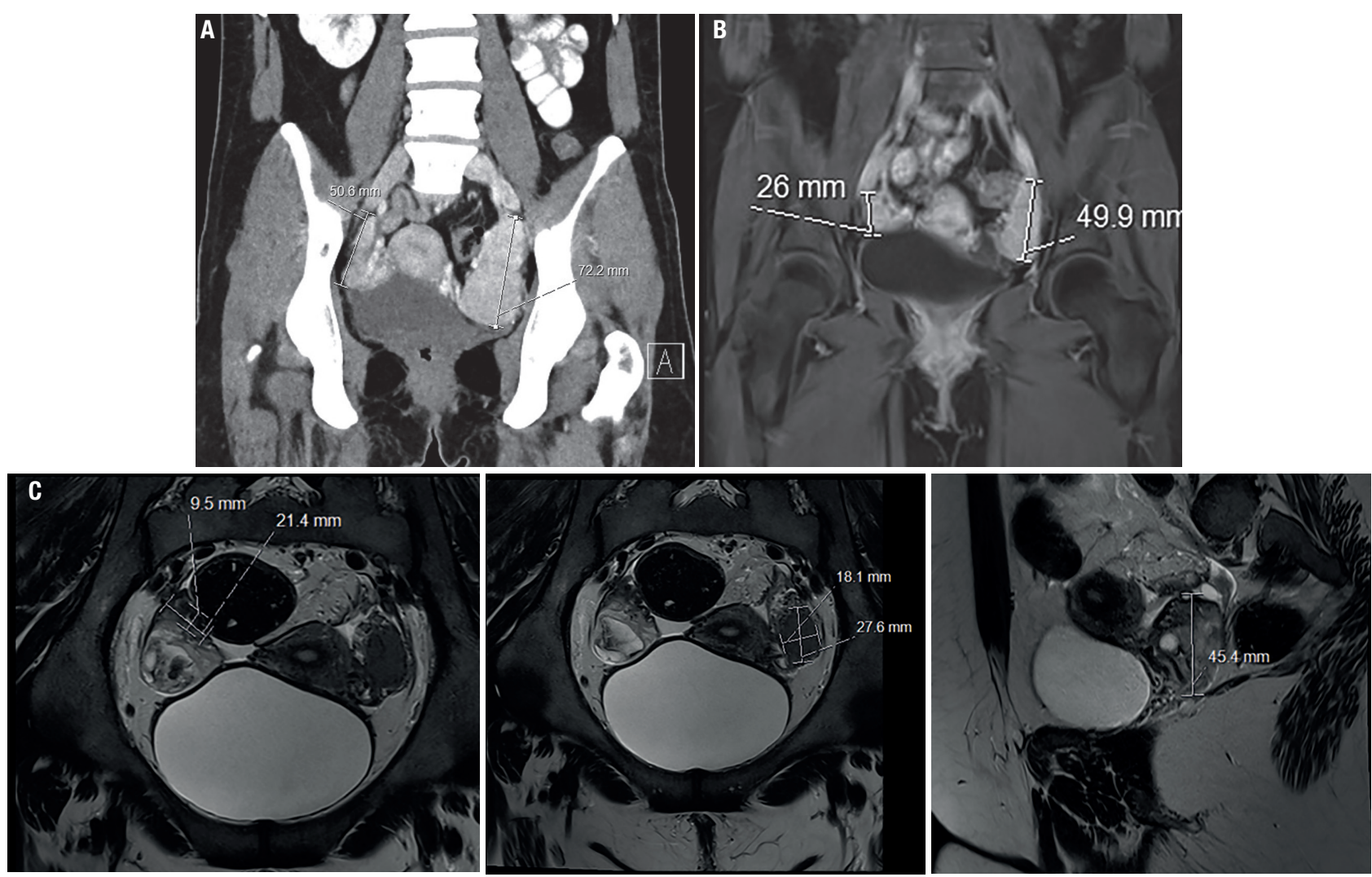

Figure 1. (A) CT scan at admission showing bilateral para-ovarian masses) $62 \times 36 \times 72 \mathrm{~mm}$ on the left, $56 \times 22 \times 32 \mathrm{~mm}$ on the right). (B) MRI scans 3 months post-admission showing as isointense in mass T1 and hypointense in T2, with early enhancement and rapid washout and significant shrinkage of the masses. (C) MRI scan 1-year post-admission showing shrinkage of the masses. 
enlarged, especially the left one. Magnetic resonance imaging (MRI) showed the masses were isointense in $\mathrm{Tl}$ and hypointense in $\mathrm{T} 2$, with early enhancement and rapid washout. A transabdominal ultrasound found the same masses, with no evidence of ovarian torsion. After one week of $300 \mathrm{mg}$ of hydrocortisone daily, significant clinical and laboratory improvements were seen, and a multidisciplinary team decided to continue the conservative approach. The patient was discharged with $2 \mathrm{mg}$ dexamethasone once daily and fludrocortisone $0.1 \mathrm{mg}$. One month later, US revealed shrinkage of the masses, and the dexamethasone dose was decreased to $\mathrm{lmg} /$ day.

At three months from discharge, we found a decrease in androgens and ACTH levels (Table 2), she had resumed regular menses, and a repeated MRI (Figure 1) revealed the para-ovarian masses had shrunk to $2.7 \times 2.4 \times 5 \mathrm{~cm}$ on the left and $1.6 \times 1.4 \times 2.3 \mathrm{~cm}$ on the right. Dexamethasone levels were decreased to 0.25 $\mathrm{mg} /$ day. It is worth noting that before presentation, the patient lost $20 \mathrm{~kg}$ over several months. Upon admission, the patient was underweight (weight: $45 \mathrm{~kg}$,

Table 1. OARTs cases reported in the literature

\begin{tabular}{|c|c|c|c|c|c|c|}
\hline Year (Ref.) & Diagnosis & Presenting age & Location & $\begin{array}{c}\text { Diagnostic } \\
\text { modality }\end{array}$ & Size & Treatment \\
\hline $1973(17)$ & $\mathrm{CAH}$ & $8 \mathrm{yrs}$ & Ovarian & Arteriography & $8 \mathrm{~cm}$ & Surgery \\
\hline $1979(15)$ & Nelson Syndr. & 35 yrs & Para-ovarian & Venous sampling & Multiple & Surgery \\
\hline $1982(18)$ & Nelson Syndr. & 49 yrs & Para-ovarian & CT / scan negative & $2 \mathrm{~cm}$ & Surgery \\
\hline 1986 (13) & Cushing Syndr. & $2 \mathrm{yrs}$ & Ovarian & - & $10 \mathrm{~cm}$ & Surgery \\
\hline 1991 (19) & CAH 11-OHD & 26 yrs & Ovarian/Leydig Tu & - & - & Surgery \\
\hline 1994 (20) & CAH-HSD3B2 & $41 \mathrm{yrs}$ & Ovarian/para-aortic & - & Multiple & Surgery \\
\hline $1998(21)$ & $\mathrm{CAH}$ & 15 yrs & Ovarian & US & Multiple & Biopsy/steroids \\
\hline 2000 (16) & СAH 11-OHD & $8.5 \mathrm{yrs}$ & Ovarian & US non-diagnostic & $2.5 \mathrm{~cm}$ & Surgery \\
\hline 2001 (14) & CAH 21-OHD & 36 yrs & Ovarian & CT & $2.8 \mathrm{~cm}$ & Surgery \\
\hline 2006 (22) & $\mathrm{CAH}$ & $0.3 \mathrm{yrs}$ & Ovarian & - & Multiple & Post-mortem \\
\hline 2010 (24) & $\mathrm{CAH}$ & 18 yrs & Ovarian & PET FDG & - & Surgery \\
\hline 2013 (23) & СAH 21-OHD & $17 \mathrm{yrs}$ & Ovarian & US / MRI & $5 \mathrm{~cm}$ & Surgery \\
\hline 2014 (25) & CAH 21-OHD & 17 yrs & Ovarian & MRl & $3+1.7 \mathrm{~cm}$ & Surgery \\
\hline \multirow[t]{3}{*}{2017 (12) } & CAH 21-OHD & $9 \mathrm{yrs}$ & Ovarian & $\begin{array}{l}\text { US/MRI non- } \\
\text { diagnostic }\end{array}$ & Multiple & Surgery \\
\hline & CAH 21-OHD & 15 yrs & Ovarian & $\begin{array}{l}\text { US/MRI non- } \\
\text { diagnostic }\end{array}$ & Multiple & Surgery \\
\hline & CAH 21-OHD & 9 yrs & Ovarian & $\begin{array}{l}\text { US/MRI non- } \\
\text { diagnostic }\end{array}$ & Multiple & Surgery \\
\hline (26) 2018 & CAH 21-OHD & 23 yrs & Para-ovarian & US / CT & $6+5 \mathrm{~cm}$ & Surgery \\
\hline Present & САH 21-OHD & 20 yrs & Para-ovarian & US / CT / MRI & $7 \mathrm{~cm}$ & Medical \\
\hline
\end{tabular}

Table 2. Androgen levels during follow up

\begin{tabular}{lcccc}
\hline & At presentation & $\begin{array}{c}\text { 3 months after } \\
\text { presentation }\end{array}$ & 1 year after presentation & Reference values \\
\hline $\mathrm{ACTH}(\mathrm{pmol} / \mathrm{L})$ & $>278$ & 249 & 8.95 & $1.1-10$ \\
$17 \mathrm{OH}-\mathrm{P}(\mathrm{nmol} / \mathrm{L})$ & 91 & 1.86 & 20 & $0.9-2.7$ \\
$\mathrm{~A}(\mathrm{nmol} / \mathrm{L})$ & 9.28 & 2.5 & 10 & $0.7-3.1$ \\
$\mathrm{DHEA}-\mathrm{S}(\mu \mathrm{mol} / \mathrm{L})$ & $>27$ & 4.99 & 25 & $3.92-10.66$ \\
$\mathrm{~T}(\mathrm{nmol} / \mathrm{L})$ & 8.3 & 1.3 & 2.6 & 0.3 and 2.4 \\
\hline
\end{tabular}

ACTH: adrenocorticotropic hormone; 17-OH-P: 17-hydroxyprogesterone; A: androstenedione; DHEA-S: dehydroepiandrosterone sulfate; T: testosterone. 
BMI: 17.5). During the treatment with high-dose steroids, her weight increased to $64 \mathrm{~kg}$ (her regular weight), but the following year, her weight increased to and remained stable at $80 \mathrm{~kg}$. She had striae on her arms and abdomen, and for a brief period, blood tests showed impaired fasting glucose levels.

One year after the diagnosis, the para-ovarian masses had shrunk to $2.8 \times 1.9 \times 4.3$ on the left (down from $4.6 \times 3.3 \times 7 \mathrm{~cm}$ ) and $2.1 \times 0.9 \times 1.2$ on the right (down from $2.5 \times 1.6 \times 3.9$ ) with less contrast enhancement in comparison to the previous test, possibly due to fibrotic changes of the tissue. In addition, multiple enlarged follicles were seen in both ovaries, implying hyperstimulation, possibly secondary to the longlasting ovarian depression. Oral contraceptives were added to the pharmaceutical regimen.

\section{DISCUSSION}

TARTs are benign tumors that histologically and functionally resemble adrenal tissue and are suspected to arise from aberrant adrenal cells that descend during fetal life with the gonads (4). They are the main cause of infertility in male patients with $\mathrm{CAH}$ due to obstruction and compression of the seminiferous tubules (5). The incidence of TARTs varies considerably (0-94\%) between series depending on the patient sample and diagnosis modality. TARTs can develop in prepubertal children, especially those with poorly controlled adrenal disease (6). Guidelines recommend sonographic screening beginning at adolescence and every 1-2 years thereafter (7). Adrenal rests are already present in embryonic life. Hence, their prevention is probably impossible (4). Treatment with glucocorticoids can achieve tumor shrinkage, though in some patients, even over suppression might not be effective (8).

In contrast to TARTS in CAH males, OARTs are very rare tumors, and their location in the para-ovarian space has been poorly described. A possible explanation for this gender difference may lie in embryological differences. During the development of the primordial sex cords, adjacent and aberrant adrenal cells can easily migrate and nestle. They will later become the rete testis and seminiferous tubules. In the female embryo, the primary sex cords regress (together with any aberrant adrenal cells nestled in them) and secondary sex cords develop (5). WNT4, a locally acting cell signal, plays an active key role in the development of the female embryo by regulating Mullerian duct formation, controlling steroidogenesis in the gonad, and possibly supporting oocyte development (9). WNT4 inhibits steroidogenic cell migration from the mesonephros into the female gonad. The Wnt4 gene is downregulated in males to allow for the coelomic vessel formation in the testis; hence, steroidogenic cell migration remains possible (10).

The imaging findings in TARTs are well described (11). The sonographic appearance is of intratesticular hypoechoic lesions, and in an MRI, they are isointense on T1- and hypointense on T2-weighted imaging and show enhancement after intravenous contrast. In a group of 13 females with treated CAH, OARTs were not detected by MRI or US according to TARTs diagnostic criteria (12). Interestingly, OARTs in a Chinese case series presented with small $(0.5 \mathrm{~cm})$ nodules discovered during surgery and not detected by imaging. (13).

Clinically significant OARTs have been reported mostly as case studies. No guidelines for the diagnosis or management of OARTs exists. We found only 17 case reports of OARTS in English language literature (13-27), documented in patients with $\mathrm{CAH}$ and various enzymatic deficiencies and patients with Nelson syndrome after bilateral adrenalectomy due to Cushing's disease (Table 1). Poor adherence to treatment and highly elevated ACTH levels were hallmarks of these cases, all but one of which were treated with surgery. In one instance, biopsies were taken with no surgical excision, followed by successful conservative management (22). Since the trigger for most CAH cases was poor adherence to medical treatment, thought should be given to optimizing surveillance and making the transition from pediatric to adult care gradually (7). To the best of our knowledge, ours is the first case in which large para-ovarian OARTs were conservatively and successfully managed based on clinical grounds rather than surgical pathology. Close follow-up is needed in these cases to ensure adherence to therapy.

Disclosure: no potential conflict of interest relevant to this article was reported.

\section{REFERENCES}

1. Witchel SF. Congenital Adrenal Hyperplasia. J Pediatr Adolesc Gynecol. 2017;30(5):520-34.

2. Reisch $N$, Rottenkolber $M$, Greifenstein A, Krone N, Schmidt $H$, Reincke $M$, et al. Testicular adrenal rest tumors develop independently of long-term disease control: a longitudinal analysis of 50 adult men with congenital adrenal hyperplasia due 
to classic 21-hydroxylase deficiency. J Clin Endocrinol Metab. 2013;98(11):E1820-6.

3. New Ml, Abraham M, Gonzalez B, Dumic M, Razzaghy-Azar M, Chitayat $D$, et al. Genotype-phenotype correlation in 1,507 families with congenital adrenal hyperplasia owing to 21-hydroxylase deficiency. Proc Natl Acad Sci U S A. 2013;110(7):2611-6.

4. Claahsen-van der Grinten HL, Hermus AR, Otten BJ. Testicular adrenal rest tumours in congenital adrenal hyperplasia. Int $\mathrm{J}$ Pediatr Endocrinol. 2009;2009:624823.

5. Claahsen-van der Grinten HL, Otten BJ, Stikkelbroeck MM, Sweep FC, Hermus AR. Testicular adrenal rest tumours in congenital adrenal hyperplasia. Best Pract Res Clin Endocrinol Metab. 2009;23(2):209-20.

6. Mendes-Dos-Santos CT, Martins DL, Guerra-Junior G, Baptista MTM, de-Mello MP, de Oliveira LC, et al. Prevalence of Testicular Adrenal RestTumor and Factors Associated with Its Development in Congenital Adrenal Hyperplasia. Horm Res Paediatr. 2018;90(3):161-8.

7. Speiser PW, Arlt W, Auchus RJ, Baskin LS, Conway GS, Merke DP, et al. Congenital Adrenal Hyperplasia Due to Steroid 21-Hydroxylase Deficiency: An Endocrine Society Clinical Practice Guideline. J Clin Endocrinol Metab. 2018;103(11):4043-88.

8. Stikkelbroeck NM, Hermus AR, Suliman HM, Jager GJ, Otten BJ. Asymptomatic testicular adrenal rest tumours in adolescent and adult males with congenital adrenal hyperplasia: basal and follow-up investigation after 2.6 years. J Pediatr Endocrinol Metab. 2004;17(4):645-53.

9. Vainio S, Heikkila M, Kispert A, Chin N, McMahon AP. Female development in mammals is regulated by Wnt-4 signalling. Nature. 1999;397(6718):405-9.

10. Jeays-Ward K, Hoyle C, Brennan J, Dandonneau M, Alldus G, Capel B, et al. Endothelial and steroidogenic cell migration are regulated by WNT4 in the developing mammalian gonad. Development. 2003;130(16):3663-70.

11. Avila NA, Premkumar A, Merke DP.Testicular adrenal rest tissue in congenital adrenal hyperplasia: comparison of MR imaging and sonographic findings. AJR Am J Roentgenol. 1999;172(4):1003-6.

12. Stikkelbroeck NM, Hermus AR, Schouten D, Suliman HM, Jager GJ, Braat DD, et al. Prevalence of ovarian adrenal rest tumours and polycystic ovaries in females with congenital adrenal hyperplasia: results of ultrasonography and MR imaging. Eur Radiol. 2004;14(10):1802-6.

13. Chen HD, Huang LE, Zhong $Z H$, Su $Z$, Jiang $H$, Zeng J, et al. Ovarian Adrenal RestTumors Undetected by Imaging Studies and Identified at Surgery in Three Females with Congenital Adrenal Hyperplasia Unresponsive to Increased Hormone Therapy Dosage. Endocr Pathol. 2017;28(2):146-51.

14. Adeyemi SD, Grange AO, Giwa-Osagie OF, Elesha SO. Adrenal rest tumour of the ovary associated with isosexual precocious pseudopuberty and cushingoid features. Eur $\mathrm{J}$ Pediatr. 1986;145(3):236-8

15. Al-Ahmadie HA, Stanek J, Liu J, Mangu PN, NiemannT,Young RH. Ovarian 'tumor' of the adrenogenital syndrome: the first reported case. Am J Surg Pathol. 2001;25(11):1443-50.

16. Baranetsky NG, Zipser RD, Goebelsmann U, Kurman RJ, March $\mathrm{CM}$, Morimoto I, et al. Adrenocorticotropin-dependent virilizing paraovarian tumors in Nelson's syndrome. J Clin Endocrinol Metab. 1979;49(3):381-6.

17. Bas F, Saka N, Darendeliler F, Tuzlali S, Ilhan R, Bundak R, et al. Bilateral ovarian steroid cell tumor in congenital adrenal hyperplasia due to classic 11beta-hydroxylase deficiency. J Pediatr Endocrinol Metab. 2000;13(6):663-7.

18. Motlik K, Starka L. Adrenocortical tumour of the ovary. (A case report with particular stress upon morphological and biochemical findings). Neoplasma. 1973;20(1):97-110.

19. Verdonk C, Guerin C, Lufkin E, Hodgson SF. Activation of virilizing adrenal rest tissues by excessive ACTH production. An unusual presentation of Nelson's syndrome. Am J Med. 1982;73(3):455-9.

20. Luton JP, Clerc J, Paoli V, Bonnin A, Dumez Y, Vacher-Lavenu MC. [Bilateral Leydig cell tumor of the ovary in a woman with congenital adrenal hyperplasia. The first reported case]. Presse Med. 1991;20(3):109-12

21. Paula FJ, Dick-de-Paula I, Pontes A, Schmitt FC, Mendonca BB, Foss MC. Hyperandrogenism due to 3 beta-hydroxysteroid dehydrogenase deficiency with accessory adrenocortical tissue: a hormonal and metabolic evaluation. Braz $\mathrm{J}$ Med Biol Res. 1994;27(5):1149-58.

22. Russo G, Paesano P, Taccagni G, Del Maschio A, Chiumello G. Ovarian adrenal-like tissue in congenital adrenal hyperplasia. $\mathrm{N}$ Engl J Med. 1998;339(12):853-4.

23. Claahsen-van der Grinten HL, Hulsbergen-van de Kaa CA, Otten BJ. Ovarian adrenal rest tissue in congenital adrenal hyperplasia - a patient report. J Pediatr Endocrinol Metab. 2006;19(2):177-82.

24. Thomas TT, Ruscher KR, Mandavilli S, Balarezo F, Finck CM. Ovarian steroid cell tumor, not otherwise specified, associated with congenital adrenal hyperplasia: rare tumors of an endocrine disease. J Pediatr Surg. 2013;48(6):E23-7.

25. Tiosano D, Vlodavsky E, Filmar S, Weiner Z, Goldsher D, BarShalom R. Ovarian adrenal rest tumor in a congenital adrenal hyperplasia patient with adrenocorticotropin hypersecretion following adrenalectomy. Horm Res Paediatr. 2010;74(3):223-8.

26. Zaarour MG, Atallah DM, Trak-Smayra VE, Halaby GH. Bilateral ovary adrenal rest tumor in a congenital adrenal hyperplasia following adrenalectomy. Endocr Pract. 2014;20(4):e69-74.

27. Sisto JM, Liu FW, Geffner ME, Berman ML. Para-ovarian adrenal rest tumors: gynecologic manifestations of untreated congenital adrenal hyperplasia. Gynecol Endocrinol. 2018;34(8):644-6. 